\title{
Delineation of Inheritance Pattern of Aleurone Layer Colour Through Chemical Tests in Rice
}

\author{
Chandu Singh ${ }^{1,2^{*}}$ D, Sripathy K.V. ', Jeevan Kumar S.P. ${ }^{1}$, Bhojaraja Naik K. ', Govind Pal', Udaya Bhaskar K. ',
} Ramesh K.V. ${ }^{1}$ and Somasundaram G. ${ }^{1}$

\begin{abstract}
Background: Rice aleurone layer develops different colours with various chemical tests that may help to develop some rapid tests for identification/grouping of rice varieties. Understanding the colour inheritance pattern could enable to develop chemical clues that may help for genetic purity analysis along with grow-out-test.

Results: In this study, inheritance pattern of aleurone layer colour was studied in parents, $F_{1}$ and $F_{2}$ progenies derived from the crosses IR $36 \times$ Acc. No. 2693 and IR $64 \times$ Acc. No. 2693. The parent IR 36 showed light yellow $(\mathrm{NaOH} / \mathrm{KOH})$ and brown (phenol/modified phenol test) colour; whereas, Acc. No. 2693 revealed wine red/dark wine red $(\mathrm{NaOH} / \mathrm{KOH})$ and light brown colour/no reaction (phenol/modified phenol test). In contrary, another parent IR 64 exhibited light yellow $(\mathrm{KOH} / \mathrm{NaOH})$ and dark brown (phenol, modified phenol) colour. Both the $\mathrm{F}_{1}$ showed an intermediate light wine red colour $(\mathrm{NaOH} / \mathrm{KOH}$ ) and dark brown (phenol and modified phenol) colour, which is dominant over their one of the parents. The colour pattern with standard phenol/modified phenol, $\mathrm{NaOH}$ and $\mathrm{KOH}$ tests in $F_{2}$ progenies of both the crosses showed 9:7 (complementary gene interaction) and 11:5 ratios (reciprocal dominance modification of recessive alleles), respectively.
\end{abstract}

Conclusions: Our findings clearly elucidate the colour inheritance pattern in rice that may facilitate to develop rapid chemical tests to identify/group the varieties for genetic purity analysis.

Keywords: Aleurone layer, Alleles, Complementary gene action, Duplicate gene action, Rice

\section{Background}

Chemical tests in rice, so far have been extrapolated for identification/characterization of cultivars on the basis of colour pattern in aleurone layer that might developed through enzyme mediated reactions. Aleurone layer is a living entity, which constitute outermost layer of endosperm, specialised in de novo synthesis of reserve mobilizing enzyme complex during seed germination process (Kumar et al. 2015). In addition, the aleurone layer is also involved in the synthesis of oxidase enzymes such as laccase, tyrosinase, polyphenol oxidase, monophenol oxidase and horse-radish peroxidase, which catalyzes to form a colour reaction (Cabaj et al. 2010; Fernandes

\footnotetext{
* Correspondence: chandusinghrathod@gmail.com

${ }^{1}$ ICAR- Indian Institute of Seed Science, Mau, Uttar Pradesh 275103, India

${ }^{2}$ Seed Production Unit, ICAR-Indian Agricultural Research Institute, New Delhi 110012, India
}

et al. 2005). Among these oxidases, polyphenol oxidase (PPO) is one of the enzyme that is involved in oxidation of phenol colour reaction through formation of brown coloured melanin pigment (Steffens et al. 1994; Kumar et al. 2016). Polyphenol oxidases avail molecular oxygen, which undergoes hydroxylation and dehydrogenation of phenolic compounds to form reactive $o$-quinones. These $o$-quinones alkylate nucleophilic groups and selfpolymerize to form melanin polymers (Fuerst et al. 2014). Role of oxidases is reported to be multifaceted, wherein they are involved in potential seed defense pathways and located in aleurone layer as indicated by their increased levels in the aleuronic fraction (Fraignier et al. 2000; Kumar et al. 2017a; Sinha et al. 2016). Proteomic analysis of aleurone layer in wheat suggested the presence of oxidases along with proteins involved in metabolism (Jerkovic et al. 2010; Kumar et al. 2017b). 
In rice, genetic studies on inheritance of colour formation in aleurone layer have been limited. However, biochemical aspects of various enzymes secreted through aleurone layer especially PPO and other reserve mobilizing enzymes have been well studied. Many workers (Joshi and Banerjee 1970; Joshi and Banerjee 1969; Jimenez and Dubcovsky 1999) studied the colour formation of wheat polyploids that had developed colour when reacted with phenol and tyrosine substrates mediated by PPO. Further, reactions of whole-wheat seeds with phenol (Joshi et al. 1969: Maguire et al. 1975) and catechol (Milner and Gould 1951) have been used for cultivar purity testing. Miczynski (1938) reported the presence of one or two genes in bread wheat, which controlled the phenol colour reaction. Moreover, various chemical tests were used so far in identification and differentiation of crop varieties based on the colour differences generated in the aleurone layer when reacted with different chemical tests. Besides, genetic background of the varieties also plays an important role in the identification of varieties. The colour formation by enzyme system has been reported in pearlmillet (Varier et al. 1995), foxtail millet (Pallares et al. 2004), sorghum (Thangavel et al. 2005), rice (Mor et al. 2006; Dileepkumar et al., 2015; Chandu et al. 2017) and wheat (Joshi et al. 2007), respectively. Chemical tests such as $\mathrm{FeSO}_{4}$ (Pallares et al. 2004), $\mathrm{KOH}$ (Mor et al. 2006), phenol and modified phenol tests (Joshi et al. 2007; Banerjee and Chandra 1977) etc. were studied for the development of seed keys. The purpose of the present study is to determine the inheritance pattern and segregation of colour formation trait in aleurone layer of rice using parents, $F_{1}$ and $F_{2}$ progenies derived from the crosses IR $36 \times$ Acc. No. 2693 and IR $64 \times$ Acc. No. 2693 by chemical tests.

\section{Results and Discussion}

Aleurone Layer Colouration in Parents IR $36 \times$ Acc. No. 2693 and IR $64 \times$ Acc. No. 2693

Studies on colour formation of aleurone layer revealed that IR 36 showed light yellow with $\mathrm{NaOH}$ and $\mathrm{KOH}$ tests, whereas, phenol and modified phenol tests recorded brown colour. The Acc. No. 2693 recorded wine red / dark wine red colour with $\mathrm{NaOH}, \mathrm{KOH}$ and light brown colour/ no reaction colour with phenol and modified phenol tests, respectively. Similarly, IR 64 recorded light yellow colour with $\mathrm{NaOH}$ and $\mathrm{KOH}$ tests; while phenol and modified phenol tests were recorded dark brown colour as shown in Table 1. Colour formation with phenol test is depicted in Fig. 1, where the genotypes were grouped based on the biochemical tests and were in congruence with other studies (Thangavel et al. 2005; Nethra et al. 2007; Vijayalakshmi and Vijay 2009; Singh et al. 2011; Anitalakshmi et al. 2014; Kumar et al. 2015).
Table 1 Aleurone layer color reaction of parents and $F_{1}$ to different chemical tests

\begin{tabular}{lllll}
\hline Chemical tests & IR 36 & IR 64 & Acc. No. 2693 & F $_{1}$ \\
\hline $\mathrm{NaOH}$ & LY & LY & WR & LWR \\
$\mathrm{KOH}$ & LY & LY & DWR & LWR \\
Phenol & B & DB & LB/NC & DB \\
Modified Phenol & B & DB & LB/NC & DB \\
\hline
\end{tabular}

LY Light Yellow, WR Wine Red, DWR Dark Wine Red, $L W R$ light wine red, $L B$ Light Brown, $B$ Brown, DB Dark Brown, NC No reaction

Aleurone Layer Colour Inheritance in $\mathrm{F}_{1}$ Plant of IR $36 \times$ Acc. No. 2693 and IR $64 \times$ Acc. No. 2693

The $\mathrm{F}_{1} \mathrm{~s}$ were derived from the crosses IR $36 \times$ Acc. No. 2693 and IR64 × Acc. No. 2693, respectively (Table 1). The freshly harvested $F_{1}$ seeds (derived from cross IR 36 $\times$ Acc. No. 2693, as depicted in Fig. 2) showed light wine red colour with $\mathrm{NaOH}$ and $\mathrm{KOH}$ tests; while brown colour was recorded with phenol and modified phenol tests, respectively.

Further, the freshly harvested $F_{1}$ seeds derived from the cross IR $64 \times$ Acc. No. 2693 (Fig. 3) showed light wine red colour with $\mathrm{NaOH}$ and $\mathrm{KOH}$ tests, respectively. In contrary, reaction with phenol and modified phenol tests showed dark brown colour, respectively. $\mathrm{NaOH}$ and $\mathrm{KOH}$ tests showed intermediate colour segregation i.e. light wine red colour compared with parents. In the same way, in case of phenol and modified phenol tests showed dark brown colour from cross IR $64 \times$ Acc. No. 2693 and the similar colour pattern was recorded in case of IR $36 \times$ Acc. No. 2693 that implies that the observed colour is dominant over light yellow.

\section{Aleurone Layer Colour Inheritance in $F_{2}$ Progenies} Derived from IR $36 \times$ Acc. No. 2693 and IR $64 \times$ Acc. No. 2693 with Standard Phenol and Modified Phenol (copper sulphate) Tests

Out of $484 \mathrm{~F}_{2}$ progenies of cross IR $36 \times$ Acc. No. 2693; 273 and $255 \mathrm{~F}_{2}$ progenies were brown/dark brown in colour, whereas 211 and $229 \mathrm{~F}_{2}$ progenies showed light brown/no colour with standard phenol and modified phenol tests, respectively. Further, $420 \mathrm{~F}_{2}$ progenies derived from cross IR $64 \times$ Acc. No. 2693 were evaluated. It is observed that 251 and $246 \mathrm{~F}_{2}$ progenies were brown/dark brown in colour; 169 and $174 \mathrm{~F}_{2}$ progenies showed light brown/no reaction with standard phenol and modified phenol tests, respectively. Therefore, the investigation revealed that the colour trait in the aleurone layer of $F_{2}$ progenies were segregated with complementary gene interaction with a ratio of 9:7 indicates a goodness of fit with observed ratio (Table 2). The $\mathrm{F}_{2}$ colour segregation was consistent with the complementary gene interaction (9:7) for all $F_{2}$ progenies of both the crosses. Therefore, two major genes and their alleles 


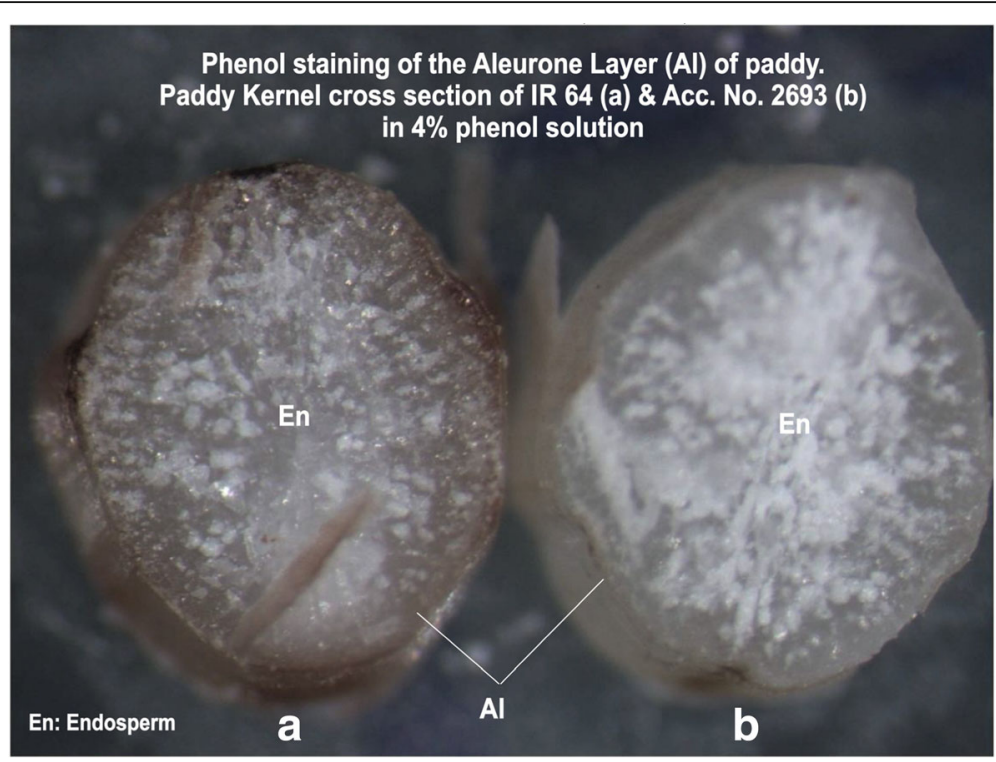

Fig. 1 Cross section of rice kernel derived from IR 64 (coloured) and Acc. No. 2693 after subjection to phenol test. Phenol staining of the Aleurone Layer (AL) of paddy. Paddy Kernel cross section of IR 64 (a) \& Acc. No. 2693 (b) in 4\% phenol solution

with complementary gene action controls the colour formation in aleurone layer.

The development of colour in aleurone layer (brown/ dark brown) with standard phenol and modified phenol tests (copper sulphate) in rice requires the presence of two dominant genes, $B_{1}$ and $D_{2}$ e.g. $B_{1} B_{1} D_{2} D_{2}$ (Fig. 4). When either $B_{1}$ (e.g. $\left.b_{1} b_{1} D_{2} D_{2}\right)$ or $D_{2}\left(B_{1} B_{1} d_{2} d_{2}\right)$ or both the genes (e.g. $b_{1} b_{1} d_{2} d_{2}$ ) are present in homozygous recessive condition, brown/ dark brown colour cannot be produced; as a result, light brown / no reactions were obtained. The brown/dark brown colour variety (IR 36 and IR 64) of rice $\left(B_{1} B_{1} D_{2} D_{2}\right)$ was crossed to a light brown/no reaction variety (Acc. No 2693) with the genotype $b_{1} b_{1} d_{2} d_{2}$ showed dark brown colour in the $F_{1}\left(B_{1} b_{1} D_{2} d_{2}\right)$ progeny. In the $F_{2}$ progenies, on an average nine progenies had one dominant allele of both the genes $B_{1}$ and $D_{2}$. These plants, therefore has brown/ dark brown colour. Three, out of sixteen $F_{2}$ progenies, shall have dominant $B_{1}$ but had homozygous recessive genotype $b_{1} b_{1}$; three others shall have dominant $D_{2}$ but had homozygous recessive genotype $\mathrm{d}_{2} \mathrm{~d}_{2}$, while one plant had both the genes in homozygous recessive genotype $b_{1} b_{1} d_{2} d_{2}$. All these (seven progenies) had light brown/no reaction. In this type of gene interaction, the production of one of the two phenotypes of colour trait requires the presence of dominant alleles of both the

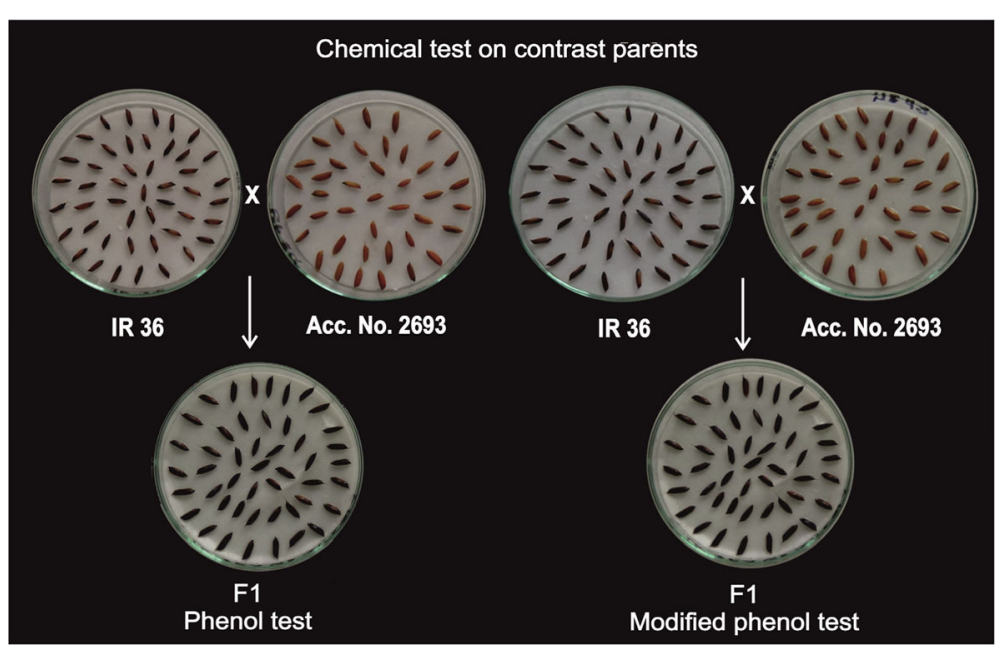

Fig. 2 Colour formation in aleurone layer of parents IR 36 (brown colour), Acc. No. 2693 (light brown/no reaction) and their $F_{1}$ progeny (brown colour) with phenol and modified phenol tests 


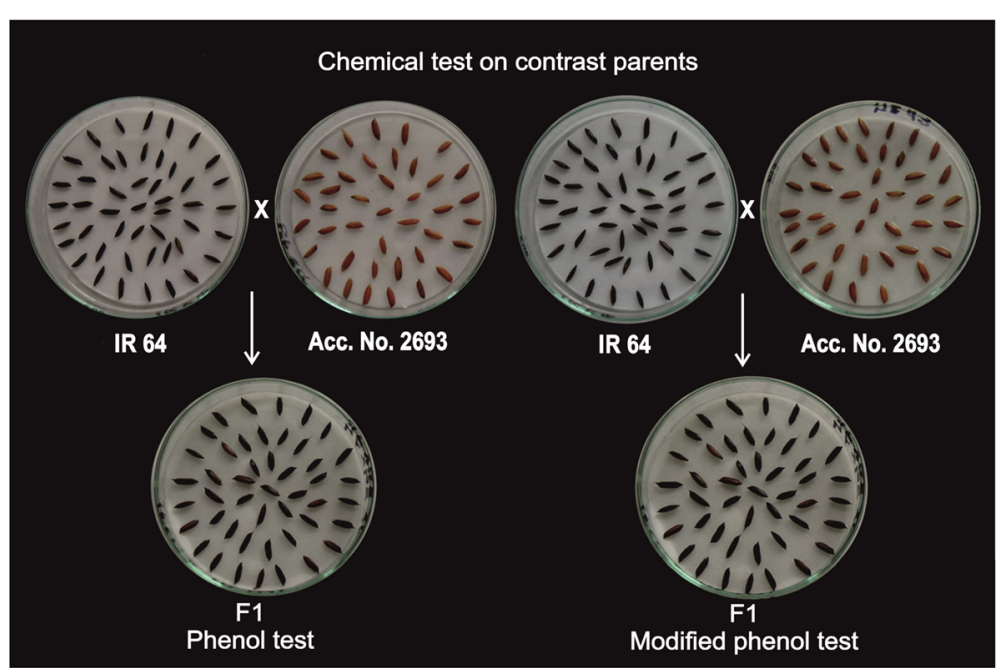

Fig. 3 Colour formation in aleurone layer of parents IR 64 (dark brown colour), Acc. No. 2693 (light brown/No reaction) and their $F_{1}$ progeny (dark brown colour) with phenol and modified phenol tests

genes controlling the concerned trait. When any one of the two or both the genes are present in the homozygous recessive state, the contrasting phenotype is produced, which leads to various modifications of the typical dihybrid, trihybrid etc. $\mathrm{F}_{2}$ ratio.

\section{The Mechanism of Colour Formation in Aleurone Layer}

Phenol test, which is an index of polyphenol oxidase activity, has been reported to be associated with intra-varietal diversity that has been used in ascertaining varietal purity. Colour formation in aleurone layer occurs by phenol oxidation in two reactions (Fig. 5). In the first reaction, the aromatic ring of phenol can be hydroxylated to form catechols or quinols, respectively. In the second reaction, the quinols or catechols undergo oxidation to form quinones (Takahashi, 1984). Two major genes and their allelic interactions control this reaction, which is localized in seed aleurone layer in rice. The ability of genotype to form colour depends on the tyrosinase activity, which is located at aleuronic layer (Masuthi et al. 2015). The extent of colour intensity among germplasms varied because of differences in enzyme activity, temperature, light, aeration and genetic background, respectively (Sivasubramanian and Ramakrishnan 1974). On the other hand, the germplasms with no colour might have resulted because of inability to hydroxylate the aromatic ring of phenol either due to shortage of electron donor or hydroxylating enzyme (Takahashi and Hamza 1983).

The results of phenol test are usually distinct and easily interpreted. Walls (1965), reported that the phenol colour reaction depends on the quality and quantity of oxidases present in the seeds, whereas Takahashi and Hamza (1983), reported that monophenol oxidase was extremely localized in aleurone layer of grains even though it is present in all other plant parts of a variety. Presence of enzyme system has been utilized to distinguish the crop varieties in rice and tomato (Pieper 1922; Joshi and Banerjee 1970; Mansing 2010; Vijayalakshmi

Table 2 Aleurone layer color segregation in F 2 progenies of the crosses IR $36 \times$ Acc.No. 2693 and IR $64 \times$ Acc. No. $2693 f o r$ standard phenol and modified phenol with copper sulphate tests

\begin{tabular}{|c|c|c|c|c|c|c|c|c|}
\hline Cross & Chemical tests & Class & $\begin{array}{l}\text { Brown/dark brown } \\
\text { colour }\end{array}$ & $\begin{array}{l}\text { Light brown/ No } \\
\text { reaction }\end{array}$ & Total & Ratio & $x^{2}$ & $\begin{array}{l}P \text { value (at } 1 \text { degrees of } \\
\text { freedom) }\end{array}$ \\
\hline \multirow{4}{*}{$\begin{array}{l}\text { IR } 36 \times \text { Acc. No. } \\
2693\end{array}$} & \multirow[t]{2}{*}{ Phenol test } & Observed & 273.00 & 211.00 & \multirow[t]{2}{*}{484} & \multirow[t]{2}{*}{$9: 7$} & \multirow[t]{2}{*}{0.005} & \multirow[t]{2}{*}{0.945} \\
\hline & & Expected & 272.25 & 211.75 & & & & \\
\hline & \multirow{2}{*}{$\begin{array}{l}\text { Modified phenol } \\
\text { test }\end{array}$} & Observed & 255.00 & 229.00 & \multirow[t]{2}{*}{484} & \multirow[t]{2}{*}{$9: 7$} & \multirow[t]{2}{*}{2.498} & \multirow[t]{2}{*}{0.114} \\
\hline & & Expected & 272.25 & 211.75 & & & & \\
\hline \multirow{4}{*}{$\begin{array}{l}\text { IR } 64 \times \text { Acc. No. } \\
2693\end{array}$} & \multirow[t]{2}{*}{ Phenol test } & Observed & 251.00 & 169.00 & \multirow[t]{2}{*}{420} & \multirow[t]{2}{*}{$9: 7$} & \multirow[t]{2}{*}{2.104} & \multirow[t]{2}{*}{0.147} \\
\hline & & Expected & 236.25 & 183.75 & & & & \\
\hline & \multirow{2}{*}{$\begin{array}{l}\text { Modified phenol } \\
\text { test }\end{array}$} & Observed & 246.00 & 174.00 & \multirow[t]{2}{*}{420} & \multirow[t]{2}{*}{$9: 7$} & \multirow[t]{2}{*}{0.920} & \multirow[t]{2}{*}{0.338} \\
\hline & & Expected & 236.25 & 183.75 & & & & \\
\hline
\end{tabular}




\section{Parents Brown / Dark brown light brown/No reaction}

$\mathbf{B}_{1} \mathbf{B}_{1} \quad \mathbf{D}_{2} \mathbf{D}_{2} \times \mathbf{b}_{1} \mathbf{b}_{1} \mathbf{d}_{2} \mathbf{d}_{2}$

Gametes

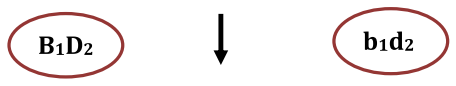

$\mathbf{B}_{1} \mathbf{b}_{1} \mathbf{D}_{2} \mathbf{d}_{2}$

F1Dark brown

\begin{tabular}{|c|c|c|c|c|}
\hline $\mathrm{F}_{2}$ 주 & $\mathbf{B}_{1} \mathbf{D}_{2}$ & $B_{1} d_{2}$ & $\mathbf{b}_{1} \mathbf{D}_{2}$ & $\mathbf{b}_{1} \mathbf{d}_{2}$ \\
\hline $\mathbf{B}_{1} \mathbf{D}_{2}$ & $\begin{array}{l}\mathrm{B}_{1} \mathrm{~B}_{1} \quad \mathrm{D}_{2} \mathrm{D}_{2} \\
\text { Brown/Dark Brown }\end{array}$ & $\begin{array}{l}\mathrm{B}_{1} \mathrm{~B}_{1} \quad \mathrm{D}_{2} \mathrm{~d}_{2} \\
\text { Brown/Dark Brown }\end{array}$ & $\begin{array}{l}\mathrm{B}_{1} \mathrm{~b}_{1} \quad \mathrm{D}_{2} \mathrm{D}_{2} \\
\text { Brown/Dark } \\
\text { Brown }\end{array}$ & $\begin{array}{l}\mathrm{B}_{1} \mathrm{~b}_{1} \quad \mathrm{D}_{2} \mathrm{~d}_{2} \\
\text { Brown/Dark Brown }\end{array}$ \\
\hline $\mathbf{B}_{1} \mathbf{d}_{2}$ & $\begin{array}{l}\mathrm{B}_{1} \mathrm{~B}_{1} \quad \mathrm{~d}_{2} \mathrm{D}_{2} \\
\text { Brown/Dark Brrown }\end{array}$ & $\begin{array}{l}\mathrm{B}_{1} \mathrm{~B}_{1} \quad \mathrm{~d}_{2} \mathrm{~d}_{2} \\
\text { Light brown/ No } \\
\text { reaction }\end{array}$ & $\begin{array}{l}\mathrm{B}_{1} \mathrm{~b}_{1} \mathrm{~d}_{2} \mathrm{D}_{2} \\
\text { Brown/Dark } \\
\text { Brown }\end{array}$ & $\begin{array}{l}\mathrm{B}_{1} \mathrm{~b}_{1} \mathrm{~d}_{2} \mathrm{~d}_{2} \\
\text { Light brown/ No } \\
\text { reaction }\end{array}$ \\
\hline $\mathbf{b}_{1} \mathbf{D}_{2}$ & $\begin{array}{l}\mathrm{b}_{1} \mathrm{~B}_{1} \quad \mathrm{D}_{2} \mathrm{D}_{2} \\
\text { Brown/Dark Brown }\end{array}$ & $\begin{array}{l}\mathrm{b}_{1} \mathrm{~B}_{1} \quad \mathrm{D}_{2} \mathrm{~d}_{2} \\
\text { Brown/Dark Brown }\end{array}$ & $\begin{array}{l}b_{1} b_{1} \quad D_{2} D_{2} \\
\text { Light brown/ No } \\
\text { reaction }\end{array}$ & $\begin{array}{l}b_{1} b_{1} \quad D_{2} d_{2} \\
\text { Light brown/No } \\
\text { reaction }\end{array}$ \\
\hline $\mathbf{b}_{1} \mathbf{d}_{2}$ & $\begin{array}{l}b_{1} B_{2} \quad d_{2} D_{2} \\
\text { Brown/Dark Brown }\end{array}$ & $\begin{array}{l}\mathrm{b}_{1} \mathrm{~B}_{1} \quad \mathrm{~d}_{2} \mathrm{~d}_{2} \\
\text { Light brown/No } \\
\text { reaction }\end{array}$ & $\begin{array}{l}b_{1} b_{1} \quad d_{2} D_{2} \\
\text { Light brown/No } \\
\text { reaction }\end{array}$ & $\begin{array}{l}\mathrm{b}_{1} \mathrm{~b}_{1} \quad \mathrm{~d}_{2} \mathrm{~d}_{2} \\
\text { Light brown/No } \\
\text { reaction }\end{array}$ \\
\hline
\end{tabular}

Phenotypic ratio: 09 Brown/dark brown: 07 Light brown/No reaction

Fig. 4 Complementary gene interaction in the development of aleurone layer colour through standard phenol and modified phenol tests in rice seed giving rise to the phenotypic ratio of 9:7 (brown/dark brown: light brown/no reaction) in $F_{2}$ progenies

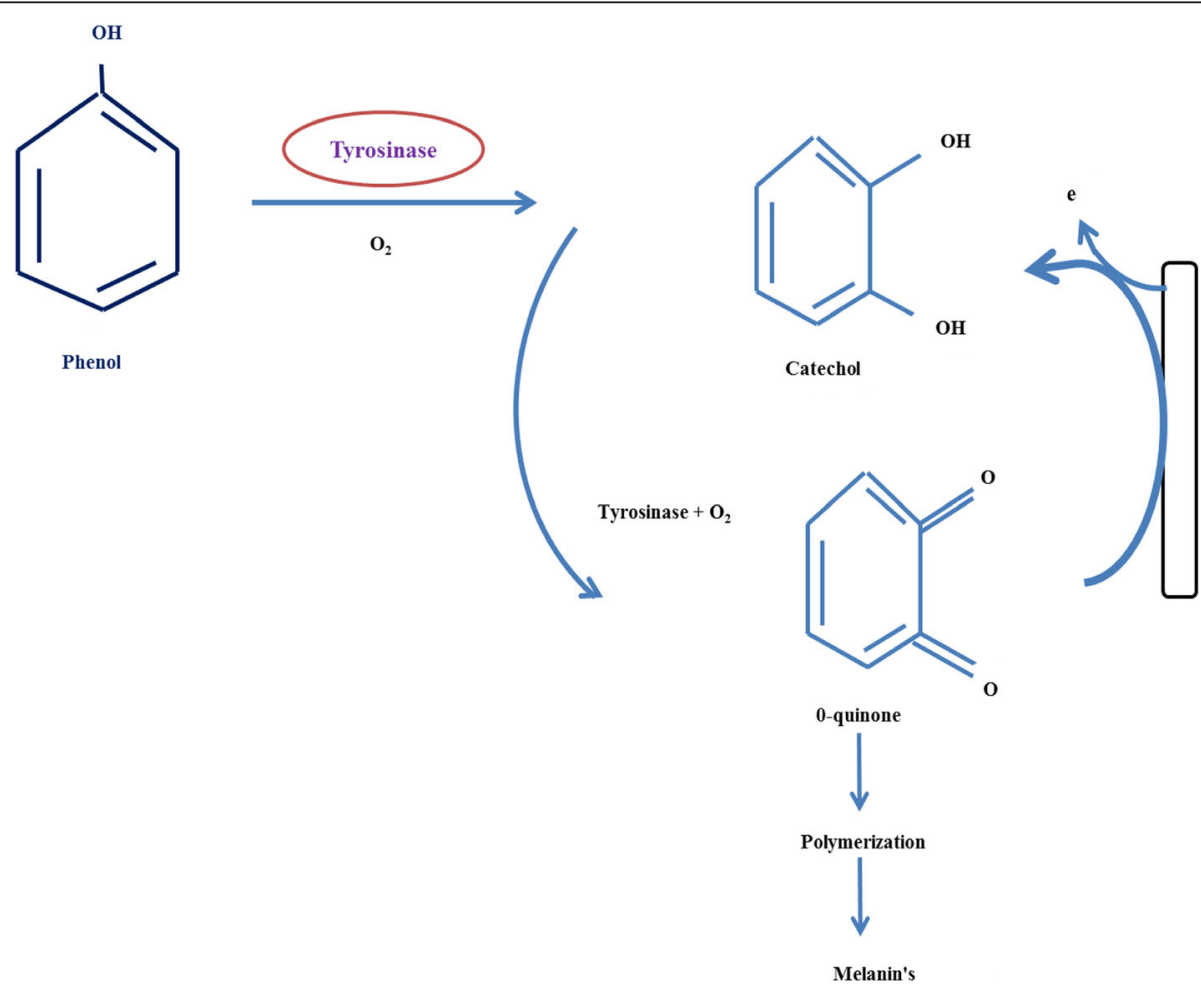

Fig. 5 Mechanism of melanin colour formation in seed aleurone layer using enzyme system upon reaction with phenol test 
and Vijay 2009; Anitalakshmi et al. 2014; Sripunitha and Sivasubramaniam 2014; Vishwanath et al. 2013).

Qian et al. (2000) reported major QTL (qPH-4a) that is responsible for phenol colour has been located on chromosome 4, which explained the total phenotypic variation as high as $94.6 \%$. Hence, this QTL is controlled by major gene. Moreover, two minor QTLs (qPH-1 and qPH-4b) located on chromosome 1 and 4 have account of total phenotypic variation of 14.9 and $29.5 \%$, respectively. Hence, minor genes that code for these QTLs, which control phenol colour have showed positive additive effects. Phenol showed a bimodal distribution in the double haploid population and a major gene detected was close to the Ph gene located on chromosome 4 (Lin et al. 1994).

\section{Aleurone Layer Colour Inheritance in $\mathrm{F}_{2}$ Population Derived from IR $36 \times$ Acc. No. 2693 and IR $64 \times$ Acc. No. 2693 with Sodium Hydroxide $(\mathrm{NaOH})$ and Potassium Hydroxide (KOH) Tests}

The $484 \mathrm{~F}_{2}$ progenies of the cross IR $36 \times$ Acc. No. 2693 were evaluated. Among them, 319 and $335 \mathrm{~F}_{2}$ progenies were wine red/dark wine red colour, whereas 165 and $149 \mathrm{~F}_{2}$ progenies were light yellow coloured with $\mathrm{NaOH}$ and $\mathrm{KOH}$ tests, respectively. Further, $420 \mathrm{~F}_{2}$ progenies derived from the cross IR $64 \times$ Acc. No. 2693 were evaluated, of which 281 and $290 \mathrm{~F}_{2}$ progenies were wine red/dark wine red colour and 139 and $130 \mathrm{~F}_{2}$ progenies were light yellow coloured with $\mathrm{NaOH}$ and $\mathrm{KOH}$ tests, respectively.

The segregation of aleurone layer colour in 11:5 ratio for wine red/dark wine red and light yellow in $F_{2}$ progenies of both the crosses showed that the colour trait is governed by two genes, where a dominance of one gene is modified by homozygous recessive condition of another gene. The two genes that interact to produce a single character may also reciprocally modify the dominance relationship between the alleles at the other locus. Thus, the typical 15:1 ratio for duplicate gene action is modified as 11:5 due to the reciprocal dominance modification of recessive alleles. This indicates a goodness of fit with expected ratio of 11:5 for the reciprocal dominance of duplicate genes as given in Table 3 .

Two genes, $\mathrm{WR}_{1}$ and $\mathrm{WR}_{2}$ showing duplicate interaction governs the development of aleurone layer colour (wine red / dark wine red/light) with $\mathrm{NaOH}$ and $\mathrm{KOH}$ in rice plants. However, the recessive homozygous condition of one gene, say $\mathrm{wr}_{1} \mathrm{wr}_{1}$ reverses the dominance relationship at the other locus; hence, the genotype $\mathrm{wr}_{1} \mathrm{wr}_{1} \mathrm{WR}_{2} \mathrm{wr}_{2}$ produces the same phenotype as the homozygous double recessive $\mathrm{wr}_{1} \mathrm{wr}_{1}, \mathrm{wr}_{2} \mathrm{wr}_{2}$ of light yellow/no reaction. Similarly, homozygous recessive condition of the other gene, $\mathrm{wr}_{2} \mathrm{wr}_{2}$ has the same effect on the dominance relationship at the $\mathrm{wr}_{1}$ locus. As a consequence, the genotype $\mathrm{WR}_{1} \mathrm{wr}_{1} \mathrm{wr}_{2} \mathrm{wr}_{2}$ produces the same phenotype as the double recessive homozygote $\mathrm{wr}_{1} \mathrm{wr}_{1} \mathrm{wr}_{2} \mathrm{wr}_{2}$ of light yellow/no reaction. Therefore, the genotypes $\mathrm{WR}_{1} \mathrm{wr}_{1} \mathrm{wr}_{2} \mathrm{wr}_{2} ; \mathrm{wr}_{1} \mathrm{wr}_{1} \mathrm{WR}_{2} \mathrm{wr}_{2}$ and $\mathrm{wr}_{1} \mathrm{wr}_{1} \mathrm{wr}_{1} \mathrm{wr}_{2}$ all produce light brown/no reaction condition. Thus, the dominant genes $\mathrm{WR}_{1}$ and $\mathrm{WR}_{2}$ behave as if, they were recessive to their allele's $\mathrm{wr}_{1}$ and $\mathrm{wr}_{2}$, respectively; whenever they are present in association with the homozygous recessive state at the other locus that is with $\mathrm{wr}_{2} \mathrm{wr}_{2}$ and $\mathrm{wr}_{1} \mathrm{wr}_{1}$, respectively as depicted in Fig. 6.

The wine red/ dark wine red colour variety (Acc. No. 2693) of rice $\left(W R_{1} W R_{1} W_{2} W_{2}\right)$ was crossed with a light yellow/no reaction variety (IR 36 and IR 64) with the genotype $\mathrm{wr}_{1} \mathrm{wr}_{1}, \mathrm{wr}_{2} \mathrm{wr}_{2}$, the derived $\mathrm{F}_{1}\left(\mathrm{WR}_{1} \mathrm{wr}_{1}\right.$ $\mathrm{WR}_{2} \mathrm{Wr}_{2}$ ) has produced light wine red colour (intermediate) even in the presence of dominant alleles of both the genes. In the $F_{2}$ generation, on an average nine plants out of 16 , have at least one dominant allele of both the genes $\mathrm{WR}_{1}$ and $\mathrm{WR}_{2}$; these plants develop wine red and dark wine red colour.

One plant has the genotype $\mathrm{WR}_{1} \mathrm{WR}_{1} \mathrm{wr}_{2} \mathrm{wr}_{2}$, while another has the genotype $\mathrm{wr}_{1} \mathrm{wr}_{1} \mathrm{WR}_{2} \mathrm{WR}_{2}$. These two plants also develop wine red and dark wine red colour; since, they have either $\mathrm{WR}_{1} / \mathrm{WR}_{2}$ in the homozygous state, which is able to produce wine red and dark wine

Table 3 Aleurone layer color segregation in F $F_{2}$ progenies of the crosses IR $36 \times$ Acc.No. 2693 and IR $64 \times$ Acc. No. 2693 for NaOH and $\mathrm{KOH}$ tests

\begin{tabular}{|c|c|c|c|c|c|c|c|c|}
\hline Cross & $\begin{array}{l}\text { Chemical } \\
\text { tests }\end{array}$ & Class & $\begin{array}{l}\text { Wine red/dark wine } \\
\text { red }\end{array}$ & $\begin{array}{l}\text { Light yellow/ No } \\
\text { reaction }\end{array}$ & Total & Ratio & $x^{2}$ & $\begin{array}{l}\text { P value(at } 1 \text { degrees of } \\
\text { freedom) }\end{array}$ \\
\hline \multirow{4}{*}{$\begin{array}{l}\text { IR } 36 \times \text { Acc. No. } \\
2693\end{array}$} & \multirow[t]{2}{*}{$\mathrm{NaOH}$} & Observed & 319.00 & 165.00 & \multirow[t]{2}{*}{484} & \multirow[t]{2}{*}{$11: 5$} & \multirow[t]{2}{*}{1.818} & \multirow[t]{2}{*}{0.178} \\
\hline & & Expected & 332.75 & 151.25 & & & & \\
\hline & \multirow[t]{2}{*}{$\mathrm{KOH}$} & Observed & 335.00 & 149.00 & \multirow[t]{2}{*}{484} & \multirow[t]{2}{*}{$11: 5$} & \multirow[t]{2}{*}{0.048} & \multirow[t]{2}{*}{0.825} \\
\hline & & Expected & 332.75 & 151.25 & & & & \\
\hline \multirow{4}{*}{$\begin{array}{l}\text { IR } 64 \times \text { Acc. No. } \\
2693\end{array}$} & \multirow[t]{2}{*}{$\mathrm{NaOH}$} & Observed & 281.00 & 139.00 & \multirow[t]{2}{*}{420} & \multirow[t]{2}{*}{$11: 5$} & \multirow[t]{2}{*}{0.665} & \multirow[t]{2}{*}{0.415} \\
\hline & & Expected & 288.75 & 131.25 & & & & \\
\hline & \multirow[t]{2}{*}{$\mathrm{KOH}$} & Observed & 290.00 & 130.00 & \multirow[t]{2}{*}{420} & \multirow[t]{2}{*}{$11: 5$} & \multirow[t]{2}{*}{0.017} & \multirow[t]{2}{*}{0.895} \\
\hline & & Expected & 288.75 & 131.25 & & & & \\
\hline
\end{tabular}




\begin{tabular}{|c|c|c|c|c|c|}
\hline & \multicolumn{3}{|c|}{$\begin{array}{c}\text { Parents Wine red / dark wine red } \\
W_{1} \mathrm{WR}_{1} \mathrm{WR}_{2} \mathrm{WR}_{2} \times \mathrm{wr}_{1} \mathrm{wr}_{1} \mathrm{wr}_{2} \mathrm{wr}_{2}\end{array}$} & \multicolumn{2}{|l|}{ Light yellow/ No reaction } \\
\hline \multicolumn{6}{|c|}{$\begin{array}{l}\text { Light wine red } \\
\text { WR }_{1} \mathrm{wr}_{1} \mathrm{WR}_{2} \mathrm{wr}_{2}\end{array}$} \\
\hline & $\mathrm{F}_{2}$ 푸 & $W_{R_{1}} W_{2}$ & $\mathrm{WR}_{1} \mathbf{w r}_{2}$ & $\mathrm{wr}_{1} \mathrm{WR}_{2}$ & $\mathbf{w r}_{1} \mathbf{w r}_{2}$ \\
\hline & $\begin{array}{l}W_{1} \\
W_{1}\end{array}$ & $\begin{array}{l}\mathrm{WR}_{1} \mathrm{WR}_{1} \mathrm{WR}_{2} \mathrm{WR}_{2} \\
\text { Wine red / Dark } \\
\text { wine red }\end{array}$ & $\begin{array}{l}\mathrm{WR}_{1} \mathrm{WR}_{1} \mathrm{WR}_{2} \mathrm{Wr}_{2} \\
\text { Wine red / Dark wine } \\
\text { red }\end{array}$ & $\begin{array}{l}\mathrm{WR}_{1} \mathrm{wr}_{1} \mathrm{WR}_{2} \mathrm{WR}_{2} \\
\text { Wine red / Dark wine } \\
\text { red }\end{array}$ & $\begin{array}{l}\mathrm{WR}_{1} \mathrm{wr}_{1} \mathrm{WR}_{2} \mathrm{wr}_{2} \\
\text { Wine red / Dark wine } \\
\text { red }\end{array}$ \\
\hline & $\begin{array}{l}\mathrm{WR}_{1} \\
\mathrm{wr}_{2}\end{array}$ & $\begin{array}{l}\mathrm{WR}_{1} \mathrm{WR}_{1} \mathrm{wr}_{2} \mathrm{WR}_{2} \\
\text { Wine red / Dark } \\
\text { wine red }\end{array}$ & $\begin{array}{l}\mathrm{WR}_{1} \mathrm{WR}_{1} \mathrm{Wr}_{2} \mathrm{Wr}_{2} \\
\text { Wine red / Dark wine } \\
\text { red }\end{array}$ & $\begin{array}{l}\mathrm{WR}_{1} \mathrm{wr}_{1} \mathrm{wr}_{2} \mathrm{WR}_{2} \\
\text { Wine red / Dark wine } \\
\text { red }\end{array}$ & $\begin{array}{l}\mathrm{WR}_{1} \mathrm{wr}_{1} \mathrm{Wr}_{2} \mathrm{Wr}_{2} \\
\text { Light yellow/No } \\
\text { reaction }\end{array}$ \\
\hline & $\begin{array}{l}\text { wr1 }_{1} \\
\text { WR2 }_{2}\end{array}$ & $\begin{array}{l}\mathrm{wr}_{1} \mathrm{WR}_{1} \mathrm{WR}_{2} \mathrm{Wr}_{2} \\
\text { Wine red / Dark } \\
\text { wine red }\end{array}$ & $\begin{array}{l}\mathrm{wr}_{1} \mathrm{WR}_{1} \mathrm{WR}_{2} \mathrm{Wr}_{2} \\
\text { Wine red / Dark wine } \\
\text { red }\end{array}$ & $\begin{array}{l}\mathrm{wr}_{1} \mathrm{wr}_{1} \mathrm{WR}_{2} \mathrm{WR}_{2} \\
\text { Wine red / Dark wine } \\
\text { red }\end{array}$ & $\begin{array}{l}\mathrm{wr}_{1} \mathrm{wr}_{1} \mathrm{WR}_{2} \mathrm{Wr}_{2} \\
\text { Light yellow/No } \\
\text { reaction }\end{array}$ \\
\hline & $\begin{array}{l}\mathbf{w r} 1 \\
\mathbf{w r} 2\end{array}$ & $\begin{array}{l}\text { wr } \mathrm{WR}_{1} \mathrm{wr}_{2} \mathrm{WR}_{2} \\
\text { Wine red / Dark } \\
\text { wine red }\end{array}$ & $\begin{array}{l}\mathrm{wr}_{1} \mathrm{WR}_{1} \mathrm{wr}_{2} \mathrm{wr}_{2} \\
\text { Light yellow/ No } \\
\text { reaction }\end{array}$ & $\begin{array}{l}\mathrm{wr}_{1} \mathrm{wr}_{1} \mathrm{wr}_{2} \mathrm{WR}_{2} \\
\text { Light yellow / No } \\
\text { reaction }\end{array}$ & $\begin{array}{l}\mathrm{wr}_{1} \mathrm{wr}_{1} \mathrm{wr}_{2} \mathrm{wr}_{2} \\
\text { Light yellow/No } \\
\text { reaction }\end{array}$ \\
\hline \multicolumn{6}{|c|}{ Phenotypic ratio: 11 Wine red/dark wine red: 05 Light yellow/No reaction } \\
\hline $\begin{array}{l}\text { Fig. } 6 \text { Dominance } \\
\text { wine red and light }\end{array}$ & $\begin{array}{l}\text { difica } \\
\text { ow/r }\end{array}$ & $\begin{array}{l}\text { of duplicate genes le } \\
\text { action colouration of }\end{array}$ & $\begin{array}{l}\text { ading to a } 11: 5 \text { phenoty } \\
\text { aleurone layer of rice se }\end{array}$ & $\begin{array}{l}\text { oic ratio in the } \mathrm{F}_{2} \text { proge } \\
\text { ed with } \mathrm{NaOH} \text { and } \mathrm{KOH}\end{array}$ & $\begin{array}{l}\text { nies for the presence of wine red / dark } \\
\text { tests }\end{array}$ \\
\hline
\end{tabular}

red colour. Two plants out of 16 are heterozygous for $\mathrm{WR}_{2}$ and homozygous for $\mathrm{wr}_{1}$ and vice versa. These four plants do not develop wine red and dark wine red colour; since, the homozygous recessive state of $\mathrm{wr}_{2}$ and $\mathrm{wr}_{1}$, reverses the dominance relationship between $\mathrm{WR}_{1} /$ $\mathrm{wr}_{1}, \mathrm{WR}_{2} / \mathrm{wr}_{2}$, respectively. The remaining one plant is also light yellow/no reaction because it is homozygous recessive for both the genes $\mathrm{wr}_{1} \mathrm{wr}_{1} \mathrm{wr}_{2} \mathrm{wr}_{2}$. Thus, the typical dihybrid 15:1 ratio for duplicate gene action is modified as 11:5 due to the reciprocal dominance modification of $\mathrm{wr}_{1}$ and $\mathrm{wr}_{2}$.

The present findings were reported in case of cotton (Fuchs et al. 1972). Two genes, $G_{1}$ and $G_{2}$ showing duplicate gene interaction governs the presence of pigment glands on cotton plants. However, the recessive homozygous condition of one gene, say $g_{1} g_{1}$, reverses the dominance relationship at the other locus so that genotype $g_{1} g_{1} G_{2} g_{2}$ produces the same phenotype as the homozygous double recessive $g_{1} g_{1} g_{2} g_{2}$. Similarly, homozygous recessive condition of the other gene, $g_{2} g_{2}$ has the same effect on the dominance relationship at the $g_{1}$ locus. As a consequence, the genotype $G_{1} g_{1} g_{2} g_{2}$ produces the same phenotype as the double recessive homozygote $g_{1} g_{1} g_{2} g_{2}$ produces glandless plants. Therefore, the genotypes $G_{1} g_{1} g_{2} g_{2}, g_{1} g_{1} G_{2} g_{2}$ and $g_{1}$ $\begin{array}{lllll}g_{1} & g_{2} & g_{2} & \text { all produce glandless condition; hence, the } F_{2}\end{array}$ phenotypic ratio 11:5 was observed. Similar classification was noticed in the present study with $\mathrm{NaOH}$, which is in congruence with the report in wheat (Mansing 2010), rice (Vanangamudi et al. 1988; Sripunitha and Sivasubramaniam 2014), urdbean (Chakrabarthy and Agrawal 1990); cotton (Ponnuswamy et al. 2003; Reddy et al. 2008), safflower (Biradar Patil et al. 2006). In addition, the same findings corroborate with the crops such as sesamum (Suhasini 2006) soybean (Chavan 2010), sunflower (Sathisha et al. 2012; Kallihal et al. 2013) and tomato (Qian et al. 2000), respectively. The reasons for various colour attributed when reacted with sodium hydroxide and potassium hydroxide might be due to inherent chemical difference, stability of genetic characters and secondary metabolites present in the seeds (Masuthi et al. 2015; Vanderburg and Vanzwol 1991; Chakrabarthy and Agrawal 1990).

Therefore, these studies are particularly useful, where non-availability of distinct stable morphological markers for identification of increased varieties. These chemical tests along with other parameters like 1000 seed weight, seed size, response to $\mathrm{GA}_{3}, 2,4-\mathrm{D}$ and soluble proteins acts as a descriptors for identification of the rice varieties. Further, these tests could help to develop a rapid varietal identification that may help the breeders and seed inspectors to monitor the quality seed production 
(Nethra et al. 2007). Thus, chemical tests are one of the important characters that help in easy identification of varieties for genetic purity.

\section{Conclusions}

Based on the response of biochemical tests with $904 \mathrm{~F}_{2}$ progenies derived from crosses, IR $36 \times$ Acc. No. 2693 and IR $64 \times$ Acc. No. 2693 were utilised for delineation of inheritance pattern of aleurone layer colour in rice. In this investigation, it was found that the colour trait in aleurone layer of the $F_{2}$ progenies derived from both the crosses were segregated with complementary gene interaction of 9:7 ratio (brown/dark brown: light brown/no reaction), indicating a goodness of fit with observed ratio for standard phenol and modified phenol tests $\left(\mathrm{CuSO}_{4}\right)$, respectively. Further, the colour trait in $\mathrm{F}_{2}$ progenies of both the crosses with $\mathrm{NaOH}$ and $\mathrm{KOH}$ tests were observed to segregate in 11:5 ratio (wine red/dark wine red: light yellow/ no reaction), wherein typical 15:1 ratio for duplicate gene action is modified as 11:5 due to the reciprocal dominance modification of recessive alleles. Therefore, it is deduced that the colour trait in aleurone layer was found to be controlled by two major genes and their allelic interactions. These findings could be utilised for easy identification of varieties in rice breeding programme, gene expression analysis, cloning and tagging of gene and also to develop the seed keys to precisely define cultivars that would serve an alternative for Grow-out-test.

\section{Methods}

\section{Plant Materials}

The present work was carried out using IR 36, IR 64 and Acc. No. 2693 (as parents), $F_{1}$ and $F_{2}$ progenies. The $F_{1} s$ were derived from cross between IR $36 \times$ Acc. No. 2693 and IR $64 \times$ Acc. No. 2693, respectively during kharif 2014 at ICAR-Directorate of Seed Research (ICARDSR), Mau, Uttar Pradesh, India. Both the crosses $\left(F_{1}\right.$ seeds) were raised during off-season 2014-15 at regional station, ICAR-DSR, GKVK campus, Bengaluru. Further, $\mathrm{F}_{2}$ progenies of both the crosses were raised during kharif - 2015 at ICAR-DSR, Mau; 484 and $420 \mathrm{~F}_{2}$ seeds of both crosses IR $36 \times$ Acc. No. 2693 and IR $64 \times$ Acc. No. 2693 were used for present investigation to delineate the inheritance pattern of colour trait in aleurone layer using chemical tests, respectively.

\section{Chemical Tests}

To know the segregation pattern of colour trait in aleuronic layer, study has been performed using different chemical tests such as standard phenol, modified phenol $\left(\mathrm{CuSO}_{4}\right)$, potasium hydroxide and sodium hydroxide tests. These chemical tests are insensitive to environment and serves not only as basis for grouping of varieties, but also used for genotype identification (Naga Padma et al. 1996) with consistent results.

\section{Phenol Test}

For phenol test, seeds were pre-soaked in distilled water for $24 \mathrm{~h}$. Thereafter, they were transferred on two layers of Whatman No.1 filter paper saturated with $4 \%$ phenol solution (Merck, Cat. No. AL8AF58565, Merck Specialities Private Ltd. Mumbai, India). The Petri-dishes were covered and incubated at $25 \pm 1{ }^{\circ} \mathrm{C}$ and the change in colour of aleurone layer in response to phenol reaction was evaluated after $24 \mathrm{~h}$. The parents, $\mathrm{F}_{1}$ and $\mathrm{F}_{2}$ progenies were categorized into five categories as no reaction, light brown, brown, dark brown and black colour (Jaiswal and Agrawal 1995).

\section{Modified Phenol Test-A $\left(\mathrm{CuSO}_{4}\right)$}

Modified phenol test was conducted, which is alike to standard phenol test except that seeds were pre-soaked in $0.5 \%(w / v)$ copper sulphate (Helix Bio-Science, Cat. No.HBC043212, New Delhi, India) solution for $24 \mathrm{~h}$. Colour reaction was noted after $48 \mathrm{~h}$ of incubation and the parents; $F_{1}$ and $F_{2}$ progenies were categorized into five categories as no reaction, light brown, brown, dark brown and black colour (Jaiswal and Agrawal 1995).

\section{Sodium Hydroxide ( $\mathrm{NaOH})$ Test}

Parents, $F_{1}$ and $F_{2}$ seeds were subjected to sodium hydroxide test where, seeds were pre-soaked in $5 \%$ sodium hydroxide solution (Merck, Cat. No. MJ8D580230, Merck Specialities Private Ltd. Mumbai, India) and kept at room temperature for one hour and change in colour of the solution was observed. Chakrabarty et al. 1989, categorized the reaction into light yellow and wine red based on the intensity of change in colour solution.

\section{Potassium Hydroxide (KOH) Test}

Seeds of parents, $F_{1}$ and $F_{2}$ progenies were pre-soaked in $5 \%$ potassium hydroxide solution (Helix Bio-Science, Cat. No. A3641, New Delhi, India) and kept at room temperature for $4 \mathrm{~h}$ and a change in colour of the solution was observed. Based on the intensity of reaction, the populations were categorized into various groups viz., light yellow, dark yellow, light wine red, dark wine red (Vanangamudi et al. 1988).

\section{Chi-square ( $\mathrm{x} 2$ ) Goodness of Fit Test}

Chi-square $\left(\mathrm{x}^{2}\right)$ goodness of fit test was performed to analyse phenotypic segregation between observed values (O) to the expected values $(\mathrm{E})$ for $\mathrm{F}_{2}$ population data, using $X^{2}=\Sigma(O-E)^{2} / E$.

\section{Abbreviations}

Acc. No.: Accession number; $B$ : Brown; $b_{1} b_{1} d_{2} d_{2}$ : Light brown/no reaction; $B_{1} B_{1}$ : Brown; $D_{2} D_{2}$ : Dark brown; DB: Dark brown; DWR: Dark wine red; ICAR: Indian Council of Agricultural Research; KOH: Potassium hydroxide; 
LB: Light brown; LWR: Light wine red; LY: Light yellow; $\mathrm{NaOH}$ : Sodium hydroxide; NR: No reaction; WR: Wine red; $w_{1} \mathrm{Wr}_{1} \mathrm{Wr}_{2} \mathrm{wr}_{2}$ : Light yellow/ no reaction; $W R_{1} W R_{1}$ : Wine red; $W R_{2} W R_{2}$ : Dark wine red

\section{Acknowledgements}

The authors are grateful to Mr. Sunil Kumar Kannaujiya and Mr. Satish Chandra Kumar for their assistance in the experimental work.

\section{Availability of Data and Materials}

The datasets for supporting the conclusions of this article have been provided in the research article.

\section{Authors' Contributions}

Conceived, Designed \& Performed the Experiments: CS. Formal analysis: CS; KBN. Contributing reagents: KVS; KUB; GS. Writing-original draft: CS; KVS. Writing-review \& editing: CS; GP; SPJK. All authors read and approved the final manuscript.

\section{Competing Interests}

The authors declare that they have no competing interests.

\section{Publisher's Note}

Springer Nature remains neutral with regard to jurisdictional claims in published maps and institutional affiliations.

Received: 16 February 2017 Accepted: 1 November 2017

Published online: 21 November 2017

\section{References}

Anitalakshmi V, Gowda R, Sathisha CS, Prasad R (2014) Varietal response to various chemical tests for their characterization in rice (Oryza sativa L.) Indian J Plant Sci 3(2):177-179

Banerjee SK, Chandra R (1977) Modified phenol test for the varietal identification of wheat seed. Seed Sci Technol 5:53-60

Biradar Patil NK, Sangeeta M, Motagi BN, Vijaykumar AG, Hanchinal RR (2006) Characterization of safflower varieties through chemical tests. Abst.XII Nation. Seed Sem, 24-26 February, ANGRAU, Hyderabad, pp.168

Cabaj J, Sołoducho J, Nowakowska-Oleksy A (2010) Langmuir-Blodgett film based biosensor for estimation of phenol derivatives. Sensors Actuators B 143(2): 508-515. 10.1016/j.snb.2009.09.047

Chakrabarthy SK, Agrawal RL (1990) Identification of black gram varieties-III: utilization of seedling growth response to added chemicals. Seed Res. 18(1):34-39

Chakrabarty SK, Agrawal RL, Bhowal (1989) Identification of blackgram varieties II. Utilization of morphological characteristics of seedlings. Seed Res 17(2):139-142

Chandu S, Jeevan Kumar SP, Sripathy KV, Somasundaram G, Udaya Bhaskar K, Ramesh KV, Madan K, Rajendra Prasad S (2017) Characterization and identification of rice germplasm accessions using chemical tests. Seed Res 45(1):75-83

Chavan NG (2010) Characterization of soybean genotypes [Glycine max (L.)Merrill] through morphological, chemical, molecular markers and image analyzer. M. Sc. Thesis submitted to University of Agricultural Sciences, Dharwad. http:// krishikosh.egranth.ac.in/bitstream/1/84304/1/th10085.pdf

Dileepkumar M, Vyakarnahal BS, Deshpande VK, Jagadeesha RC, Mukesh L, Chavan, Khaja RS (2015) Characterization of traditional aromatic rice cultivars by chemical markers. Int J Adv Res 3(5):103-107

Fernandes KF, Lima CS, Lopes FM, Collins CH (2005) Hydrogen peroxide detection system consisting of chemically immobilised Peroxidase and spectrometer. Process Biochem 40(11):3441-3445

Fraignier MP, Michaux-Ferriere N, Kobrehel K (2000) Distribution of peroxidases in durum wheat (Triticum durum). Cereal Chem 77:11-17. 10.1094/CCHEM.

Fuchs JA, Smith JD, Birds LS (1972) Genetic basis for an 11:5 dihybrid ratio observed in Gossypium hirsutum. J Hered 63:300-303

Fuerst EP, Okubara PA, Anderson JV, Morris CF (2014) Polyphenol oxidase as a biochemical seed defense mechanism. Front Plant Sci 5:689

Jaiswal JP, Agrawal RL (1995) Varietal purity determination in rice: modification of the phenol test. Seed Sci Technol 23:33-42

Jerkovic A, Kriegel AM, Bradner JR, Atwell BJ, Roberts TH, Willows RD (2010) Strategic distribution of protective proteins within bran layers of wheat protects the nutrient-rich endosperm. Plant Physiol 152(3):1459-1470

Jimenez M, Dubcovsky J (1999) Chromosome location of genes affecting polyphenol oxidase activity in seeds of common and durum wheat. Plant Breed 118:395-398
Namrata-Gupta, Joshi MA, Sarao NK, Sharma RC (2007) Utility of phenol test in varietal characterization. Crop Improv 34(1):77-81

Joshi MG, Banerjee SK (1969) Multiple alleles for phenol colour reaction in emmer wheat. Indian J. Genet. Plant Breed 29(2):280-284

Joshi MG, Banerjee SK (1970) Genetics of phenol colour reaction in emmer wheat. Proc Int Seed Assoc 35:207

Joshi MG, Banerjee SK, Naik MS (1969) Tyrosinase activity as a quantitative indicator of genetic control of phenol colour reaction in tetraploid triticums. Indian J Exp Biol 7:189-190

Kallihal PK, Rajendra Prasad S, Shwetha KS (2013) Characterization of sunflower (Helianthus annuus L.) hybrid and its parental lines based on biochemical tests at seed and seedling stages. Annals Biol Res 4(4):96-99

Kumar SPJ, Kumar VG, Dash A, Scholz P, Banerjee R (2017) Sustainable green solvents and techniques for lipid extraction from microalgae: a review. Algal Res 21:138-147

Kumar SPJ, Prasad SR, Banerjee R, Agarwal DK, Kulkarni KS, Ramesh KV (2017) Green solvents and technologies for oil extraction from oilseeds. Chem Central J 11:1-9

Kumar SPJ, Rajendra Prasad S, Banerjee R, Thammineni C (2015) Seed birth to death: dual functions of reactive oxygen species in seed physiology. Ann Bot 116(4):663-668

Kumar SPJ, Rajendra Prasad S, Kumar M, Singh C, Sinha AK, Pathak A (2016) Seed quality markers: a review. Res Rev S3:13-17

Lin SY, Nagamura N, Kurata M (1994) DNA markers tightly linked to genes. Ph. Alk and Rc. Rice Genet Newslett 11:108

Maquire JD, Steen KM, Grzelak K (1975) Classification of pacific northwest winter and spring wheat cultivars by phenol reactions. Proc. off. Assn. Seed Analysts 65:143-146

Mansing JS (2010) Characterization of wheat (Triticum spp.) genotypes trough morphological, chemical and molecular markers. M.Sc. (Agri.) thesis submitted to University of Agricultural Sciences, Dharwad. http://krishikosh. egranth.ac.in/handle/1/84530

Masuthi D, Vyakarnahal BS, Deshpande VK, Jagadeesha RC, Mukesh LC, Khaja Rubina S (2015) Characterization of traditional aromatic rice cultivars by chemical markers. Int J Adv Res 3(5):103-107

Miczynski K (1938) Genetische Studien fiber die Phenol Farben Reaktion beim Weizen. Z, zucht 22:564-587

Milner M, Gould MR (1951) The quantitative determination phenol oxidase activity in wheat varieties. Cereal Chem 28:473-478

Mor RS, Battan KR, Mehla BS (2006) Identification of rice varieties by laboratory techniques. National J PI Improvement 8(1):28-31

Naga Padma K, Muralimohan RB, Ankaiah R, Sarada P (1996) Characterisation of twenty-three maize inbred lines through seed morphology, leaf stomatal studies and response of seedlings to added chemicals. Seed Res 24(1):15-19

Nethra N, Rajendra Prasad S, Vishwanath K, Dhanraj KN, Gowda R (2007) Identification of rice hybrids and their parental lines based on seed, seedling characters, chemical tests and gel electrophoresis of Total soluble proteins. Seed Sci Technol 35:176-186

Pallares IN, Ferrari L, Postulka EB, Ritta MN (2004) Identification of cultivars of foxtail millet (Setaria italica (L.) Beauv.) from morphological and biochemical traits of their seed. Seed Sci Technol 32(1):187-196

Pieper H (1922) Ein Mittel zur Unterscheidung von Weizensorten am Korn. Deutsche Lantwritschaftlinche Presse 49(67):438-439

Ponnuswamy AS, Bhaskaran M, Sastri G (2003) Variety characterization in cotton by physical, chemical and bio-chemical methods. In: Training Mannual, variety characterization by image analysis and electrophoresis, pp 106-120

Qian Q, He P, Zheng X, Ying C, Zhu L (2000) Genetic analysis of morphological index and its related taxonomic traits for classification of indica/japonica rice. Sci China (series C) 43(2)

Reddy M, Hunje R, Nadaf HL, Biradar DP, Vyakarnahal BS (2008) Identification of cotton hybrids and parents through chemical tests. Agril Sci Digest 28(1):51-53

Sathisha CS, Rajendra Prasad S, Gowda R, Thimmegowda MN (2012) Comparison of various chemical tests for varietal characterization in sunflower (Helianthus annuus L.). Indian J. Plant Sci 1(1):39-43

Singh D, Kumar A, Kumar N, Kumar V, Kumar S, Bhardwaj A, Sirohi P, Chand S (2011) Comparison of traditional physico-chemical methods and molecular marker assays for characterization of basmati rice (Oryza sativa L.). African J. Of. Biotechnology 10(62):13390-13398

Sinha AK, Agarwal DK, Kumar SPJ, Chaturvedi A, Tiwari TN (2016) Novel technique for precluding hybrid necrosis in bread wheat. Int J Tro Agr 34(3): $761-765$

Sivasubramanian S, Ramakrishnan V (1974) Use of phenol colour reaction for identification of rice varieties. Exp Agric 10:299-303 
Sripunitha A, Sivasubramaniam K (2014) Varietal characterization rice varieties based on chemical methods. Trends Biosci 7(20):3139-3146

Steffens JC, Harel E, Hunt MD (1994) Polyphenol oxidase. In: Ellis BE et al (eds) Genetic engineering of plant secondary metabolism. Plenum Press, New York, pp 275-313

Suhasini KS (2006) Characterization of sesame genotypes through morphological, chemical and RAPD markers. M.Sc (Agri.) Thesis submitted to University of Agricultural Sciences, Dharwad. http://krishikosh.egranth.ac.in/handle/1/81949

Takahashi N (1984) Differentiation of ecotypes in Oryza sativa L. In: Takahashi N, Tsunoda S (eds) Biology of Rice. Japan Scientific Societies Press, Tokyo, pp 31-67

Takahashi N, Hamza AHA (1983) Differentiation of ecotypesin Oryza sativa L. I: reexamination for colour reaction with phenol. Japanese J Breed 33(3):243-250

Thangavel P, Bharathi A, Natarajan N, Evera T (2005) Varietal grouping in sorghum by seed and seedling morphology and response to chemical testing. Karnataka JAgric Sci. 18 (3): 664-672.

Vanangamudi K, Palanisamy V, Natesan P (1988) Variety determination in rice phenol and potassium hydroxide tests. Seed Sci Technol 16:465-470

Vanderburg NJ, Vanzwol RA (1991) Rapid identification techniques used in laboratories of the international seed testing association: a survey. Seed Sci Technol 19:687-700

Varier A, Dadlani M, Sharma SP (1995) Phenol test and electrophoresis of seed esterases for testing genetic purity in seed lots of pearl millet (Pennisetum glaucum) inbreds. Indian J Agri Sci 65(11):789-792

Vijayalakshmi B, Vijay D (2009) Development of seed keys for varietal identification in Rice (Oryza sativa L.) using chemical tests. Seed Res 37(1\&2): $56-61$

Vishwanath K, Pallavi HM, Nethra N, Rajendra Prasad S (2013) Chemical tests for identification and characterization of tomato cultivars. Plant Breed Seed Sci 68:3-12

Walls WE (1965) A standardized phenol method for testing wheat seed for varietal purity. Contribution no. 28 to the Handbook on Seed Testing. The Assoc. of Official Seed Analysts, Lincoln, NE.

\section{Submit your manuscript to a SpringerOpen ${ }^{\circ}$ journal and benefit from:}

- Convenient online submission

- Rigorous peer review

- Open access: articles freely available online

- High visibility within the field

- Retaining the copyright to your article

Submit your next manuscript at $\boldsymbol{s p r i n g e r o p e n . c o m ~}$ 